Article

\title{
Heavy Metal Retention by Different Forest Species Used for Restoration of Post-Mining Landscapes, N. Greece
}

\author{
Theano Samara *, Ioannis Spanos, Panagiotis Platis and Thomas G. Papachristou
}

Forest Research Institute of Thessaloniki, ELGO-DEMETER, 57006 Thessaloniki, Greece; ispanos@fri.gr (I.S.); pplatis@fri.gr (P.P.); thomas.papachristou@fri.gr (T.G.P.)

* Correspondence: theasam@fri.gr; Tel.: +30-2310-461172-(205)

Received: 11 May 2020; Accepted: 27 May 2020; Published: 30 May 2020

check for updates

\begin{abstract}
The main objective of this research was to study heavy metal absorption by the leaves of main forest species which were planted for that purpose at post-lignite mining landscapes in Northern Greece (Ptolemais, Prefecture of Kozani), as well as in a neighboring region (Kato Grammatiko), $30 \mathrm{~km}$ far from the mining area. Four species were studied; two conifers (Pinus nigra Arn., Cupressus arizonica Greene) and two broad-leaved (Robinia pseudoacacia L., Populus nigra L.). The four species varied in their leaf morphology (needles, scale-like leaves, blade, compound or simple, with rough or smooth surfaces). Eighty (80) leaf samples were collected, (10 from each tree species at either site). The heavy metal concentrations measured were iron $(\mathrm{Fe})$, copper $(\mathrm{Cu})$, chromium $(\mathrm{Cr})$, nickel $(\mathrm{Ni})$, cadmium $(\mathrm{Cd})$, manganese $(\mathrm{Mn})$, zinc $(\mathrm{Zn})$ and cobalt $(\mathrm{Co})$. Statistically significant differences $(p=0.01)$ were found between the lignite deposit and control areas and among the studied species. Higher concentrations were measured for the studied species at the lignite deposit. Moreover, no species demonstrated maximum absorption for all metals. The metal absorption pattern by coniferous trees' leaves at the mining landscape was similar, with highest concentrations observed for iron and lowest for cobalt iron $(\mathrm{Fe})>$ zinc $(\mathrm{Zn})>$ manganese $(\mathrm{Mn})>\operatorname{copper}(\mathrm{Cu})>\operatorname{chromium}(\mathrm{Cr})>$ nickel $(\mathrm{Ni})>$ cobalt $(\mathrm{Co})]$. Both broadleaved species absorbed highest concentrations of iron, but differed in the amount of the remaining metals [black locust: iron $(\mathrm{Fe})>$ manganese $(\mathrm{Mn})>\mathrm{zinc}(\mathrm{Zn})>$ copper $(\mathrm{Cu})>$ nickel $(\mathrm{Ni})>$ chromium $(\mathrm{Cr})$; black poplar: iron $(\mathrm{Fe})>$ zinc $(\mathrm{Zn})>$ manganese $(\mathrm{Mn})>$ copper $(\mathrm{Cu})>\operatorname{nickel}(\mathrm{Ni})>$ chromium $(\mathrm{Cr})>$ cobalt $(\mathrm{Co})]$. Cadmium was detected only in black poplar at both sites. In general, black pine was found to absorb the highest concentration of iron (Fe), and black poplar zinc $(\mathrm{Zn})$. We discuss the importance of carefully selecting the appropriate mixture of tree species in order to achieve maximum habitat restoration effect at heavy metal polluted sites.
\end{abstract}

Keywords: lignite mines; silvicultural characteristics; air pollution; leaf morphology

\section{Introduction}

Lignite is enriched with heavy metals during its mineral formation stage, which, during combustion, are emitted in the form of suspended particles or accumulated in the produced ash [1]. Lignite power stations produce the highest percent of electricity in Greece. Four such stations, with a combined $>4000$ MW capacity, are located in the prefectures of Kozani and Florina, in western Macedonia. The heavy metals in the fly ashes are very important because they are mixed with overburden and interbedded sediments and then used as landfill. There are no globally accepted limits on what heavy metals concentrations are hazardous to living organisms. Likewise, there is no national regulation that defines the maximum metal concentrations in nonhazardous sewage for land applications, except in the case of waste sludge (86/278/EEC) [2]. 
The restoration of old mine areas, where lignite has been exhausted, and their return to agricultural, woodland and environmental activities, is one of the goals of the Public Power Corporation (PPC). To achieve this, the corporation plants woody species to remove pollutants from the environment or to render them harmless; a process referred to as phytoremediation. Many kinds of plant tissues have been used in the past as pollution biorecorders (mosses, lichens, tree barks and leaves). In industrial and urban areas, where there are no mosses and lichens, the research is performed on trees. Evergreen coniferous and deciduous broadleaved trees have been used in studies examining air pollution by heavy metals. Many researchers stressed the importance of using tree leaves as pollution bioindicators [3-9]. Lead and chromium are absorbed directly from the air by the plants' leaves and not from the roots [7]. In many cases, plants seem to accumulate heavy metals, such as lead, in their cell walls in high concentrations [10]. Compared to lichens and mosses, woody plants (e.g., shrubs, trees) have the advantage as pollution bioindicators that they occur in a larger range of habitats, therefore being a management option for more sites [11,12].

Trees reduce air pollution in two ways: with direct removal of pollutants from the air, and with indirect reduction through preventing the creation of secondary air pollutants. Direct reduction is carried out through pollutant absorption by the root system and stomata of leaves. At the same time, the crown of the trees stops pollutant movement and diffusion [13] by absorbing them, via the wet surface of their leaves [14]. Indirect pollution reduction occurs due to the tree's cooling effect of the atmosphere temperature (via shading and evapotranspiration mechanisms), which in turn leads to lower rates of chemical reactions in the atmosphere and the ensuing production of secondary pollutants [15,16].

The main objective of this research is to evaluate the role of the main forest species against pollution planted in northern Greece for the restoration of PPC mines, in order to identify the most appropriate tree species (or combination) for future use. To achieve this, we examined the heavy metal concentration in leaves of the main forest species planted in the region for this purpose, and the effect of the morphological features of leaves on heavy metal concentration.

\section{Materials and Methods}

\subsection{Study Area}

Field work was carried out in the Ptolemais-Amyntaio basin, which is located in the Kozani and Florina prefectures of Western Macedonia, where the biggest lignite deposits of Greece are found [17]. The soils of the region are characterized by maroon color and are shallow $(15-30 \mathrm{~cm})$. A disadvantage of this type of soils is the lack of moisture, as they are well-drained, hot and drier than other bedrock soils [18].

Four lignite power stations located in western Macedonia produce in excess of $70 \%$ of the country's electrical power requirements [19]. About $64 \mathrm{Mt}$ of lignite are produced annually from the four mines and are transported to the power stations by rail trucks and conveyor belts [20]. Assuming that about $15 \%$ of the lignite is transformed to ash and the electrostatic precipitators have the ability to retain $99.9 \%$ of it, $9.6 \mathrm{kt}$ of fly ash are released annually [21,22].

The climate is characterized as semi-arid, Mediterranean to continental. According to the meteorological stations of the area, the 55-yr maximum monthly temperature averages $29.3{ }^{\circ} \mathrm{C}$ (July and August) and the corresponding minimum temperature $-2.1^{\circ} \mathrm{C}$ (January). The relevant humidity during wet and dry period ranges from $70 \%-80 \%$ and in the dry and hot period, $50 \%-60 \%$. Pursuant to the information of the meteorological station of Pontokomi for the last 35 years, the highest average monthly precipitation is from October-December (50-70 $\mathrm{mm}$ of rain), while the lowest is from June-August period $(30-35 \mathrm{~mm})$. The average annual rainfall amount in the area for the above time period was $504.5 \mathrm{~mm}$. 


\subsection{Methods}

The research was carried out in the main lignite field of PPC-Ptolemais and on non-mined neighboring areas (Kato Grammatiko). Kato Grammatiko is located $28.8 \mathrm{~km}$ northeast from the main field of PPC. There is evidence that at $10 \mathrm{~km}$ towards the direction of the wind, sulfur dioxide $\left(\mathrm{SO}_{2}\right)$ and heavy metal concentrations are at normal levels [23]. Therefore, the control area (K. Grammatiko) was considered to be appropriate for the comparison with wooded mining landscapes. A variety of forest species have been planted in the past in the study area. However, four species, Cupressus arizonica Green (Arizona cypress), Pinus nigra Arn (black pine), Robinia pseudoacacia L. (black locust), and Populus nigra L. (black poplar), dominate in the landscape. Therefore, we decided to study these species, of which the first two are coniferous evergreen trees, while the other two are broad-leaved deciduous trees. Leaf morphology differs among the four species; i.e., black pine's needles are rough and Arizona cypress's scale-like, while black locust leaves are compound and black poplar's lamina [24-30].

We collected leaves from ten trees of each species at each site $(n=80)$. The samples were collected from the same part of the plants, since the content in heavy metals varies depending on the part of the plants [31]. The leaves were collected from the four points of the horizon [32,33] and at a fixed height of 1.5 to $2.0 \mathrm{~m}$ from the ground [27].

The sampled trees were selected using systematic sampling. The repetitions are of vital importance, since pollutant concentration may vary among different species and even for the same species [31]. The trunk circumference at breast height $(\mathrm{cm})$ and height $(\mathrm{m})$ of each sampled tree were measured using a tape measure and a Haga altimeter respectively. Leaf sampling was carried out in August (xerothermic period), following Kovác's suggestion [34] that standardized sampling for research on heavy metal accumulation for the black poplar in central Europe should be carried out in August. In addition, for the most deciduous species, summer is the period of the year in which heavy metal content in leaves is higher [34,35]. Sawidis et al. [27] found that the highest average copper $(\mathrm{Cu})$ and zinc $(\mathrm{Zn})$ concentrations in foliage were detected in autumn in comparison with spring.

Leaf samples (approximately $200 \mathrm{~g}$ ) were collected in the morning between 09:00 and 12:00 h, placed in paper bags and oven-dried at $80^{\circ} \mathrm{C}$ for $24 \mathrm{~h}$. Then, they were ground in an electric mill, sieved (0.2 mm Culatti 220 Model, 301122) and stored in plastic bags. All measurements were carried out on fully developed leaves, undamaged by insects, and with no color differentiations. For evergreen coniferous species, biennial needles were selected [36-39].

Chemical analyses were carried out to determine manganese $(\mathrm{Mn})$, zinc $(\mathrm{Zn})$, copper $(\mathrm{Cu})$, iron (Fe), cadmium (Cd), chromium (Cr), cobalt (Co) and nickel (Ni) levels. Specifically, 1 gr of the dried, ground and sieved matter samples was heated overnight $(16 \mathrm{~h})$ at $550{ }^{\circ} \mathrm{C}$ in a muffle furnace and cooled in a desiccator to room temperature. Afterwards, $5 \mathrm{~mL} \mathrm{HCl} 6 \mathrm{~N}$ were added in the samples to dissolve the ash. The remains were placed in $50 \mathrm{~mL}$ volumetric flasks, topped up with water. The metal concentration was determined in the diluted ash by using an ICP-OES (Perkin Elmer Optical Emission Spectrometry, Optima 2100 DV) inductively coupled plasma optical emission spectrometer [40-48]. The respective wave lengths, which were used and the lowest detectable metal concentration according to instrument's specifications, were: (1) for Fe $238.204 \mathrm{~nm}$ and $0.0046 \mathrm{ppm}$, (2) for Mn $257.610 \mathrm{~nm}$ a 0.0014 ppm, (3) for Zn $206.200 \mathrm{~nm}$ and $0.0059 \mathrm{ppm}$, (4) for Cu $327.393 \mathrm{~nm}$ and $0.0097 \mathrm{ppm}$, (5) for Cd $228.802 \mathrm{~nm}$ and $0.0027 \mathrm{ppm}$, (6) for Co $228.616 \mathrm{~nm}$ and $0.0070 \mathrm{ppm}$, (7) for Cr $267.716 \mathrm{~nm}$ and 0.0071 ppm and (8) for Ni $231.604 \mathrm{~nm}$ and $0.015 \mathrm{ppm}$, respectively.

\subsection{Statistical Analysis}

We tested for differences in the heavy metal levels of the samples using analysis of variance/general linear models $[49,50]$. The experimental design was a $2 \times 4$ factorial completely randomized design. Significant differences among means were detected by the Tukey's test. The Tukey test was chosen in order to reduce the expantion Error Type I cumulative rate [51]. Statistical analyses were carried out by SPSS statistical package v 17.0 (SPSS Inc., Chicago, IL, USA). Prior to analysis, the metal concentrations 
were $\log$ transformed, in order to homogenize error variances. All means were separated using least significance differences $(p \leq 0.05)$.

\section{Results}

\subsection{Forest Tree Growth}

Ecological research on natural vegetation in fly and bottom ash deposits have indicated a number of negative effects that ash has on plant survival and growth. The major factors that limit the establishment and growth of vegetation on ash disposal sites are as follows: lack of crucial nutrients such as $\mathrm{N}$ and $\mathrm{P}$, high $\mathrm{pH}$ toxicity and/or high soluble salt concentrations, high concentrations of $\mathrm{B}$ and other toxic heavy metals, and the presence of compacted and/or cemented layers in the ash [52-56]. The studied forest species, in the mining landscape, i.e., black pine, Arizona cypress, black locust and black poplar, had the following values of mean diameter at breast height and mean height (means \pm s.e.): $22.80 \pm 0.95,10.60 \pm 0.97,13.40 \pm 0.54$ and $19.80 \pm 1.30 \mathrm{~cm}$, respectively, and $6.65 \pm 0.42,7.03 \pm 0.81$, $11.10 \pm 0.43$ and $10.48 \pm 1.01 \mathrm{~m}$, respectively. The respective values of the plant species in the control area were: $23.60 \pm 0.67,16.90 \pm 1.77,25.30 \pm 2.00$ and $46.90 \pm 4.36 \mathrm{~cm}$, respectively, and $6.80 \pm 0.36$, $7.30 \pm 0.54,17.20 \pm 0.27$ and $18.50 \pm 0.98 \mathrm{~m}$, respectively.

\subsection{Metal Retention}

The mean concentrations of cadmium, cobalt, chromium, copper, iron, manganese, nickel and zinc of the tree leaves are given in Table 1.

Table 1. Heavy metal concentration $(\log 10(X+1)$ transformed values) in the mining landscape and in the controlled area $(\mathrm{ppm})^{1}$.

\begin{tabular}{cccccc}
\hline Area & Heavy Metals & \multicolumn{3}{c}{ Species } \\
\hline Mining & & Pinus nigra & Cupressus arizonica & Robinia pseudoacacia & Populus nigra \\
landscape & $\mathrm{Cd}$ & $0(0)$ & $0(0)$ & $0.061(0.158)$ & $0.137(0.384)$ \\
& $\mathrm{Co}$ & $0.051(0.145)$ & $0.081(0.230)$ & $0(0)$ & $0.066(0.204)$ \\
& $\mathrm{Cr}$ & $0.537(2.566)$ & $0.389(1.491)$ & $0.477(2.053)$ & $0.367(1.367)$ \\
& $\mathrm{Cu}$ & $0.741(4.584)$ & $0.807(5.480)$ & $1.171(13.919)$ & $0.948(8.187)$ \\
& $\mathrm{Fe}$ & $2.479(313.223)$ & $2.239(184.839)$ & $2.321(211.108)$ & $2.001(100.678)$ \\
& $\mathrm{Mn}$ & $1.148(13.357)$ & $1.265(20.959)$ & $1.414(25.447)$ & $1.229(16.508)$ \\
& $\mathrm{Ni}$ & $0.501(2.217)$ & $0.323(1.258)$ & $0.737(4.620)$ & $0.473(2.249)$ \\
& $\mathrm{Zn}$ & $1.149(13.16)$ & $1.291(19.41)$ & $1.364(22.39)$ & $1.893(87.61)$ \\
\hline \multirow{2}{*}{ Control } & $\mathrm{Cd}$ & $0.146(0.403)$ & $0(0)$ & $0(0)$ & $0.152(0.208)$ \\
& $\mathrm{Co}$ & $0.026(0.71)$ & $0.032(0.090)$ & $0(0)$ & $0.187(0.604)$ \\
& $\mathrm{Cr}$ & $0.310(1.056)$ & $0.204(0.657)$ & $0.469(1.998)$ & $0.454(1.939)$ \\
& $\mathrm{Cu}$ & $0.789(5.186)$ & $0.763(5.253)$ & $0.962(8.585)$ & $1.022(9.616)$ \\
& $\mathrm{Fe}$ & $2.113(130.280)$ & $2.017(105.858)$ & $2.037(112.127)$ & $2.107(128.193)$ \\
& $\mathrm{Mn}$ & $1.397(24.777)$ & $1.572(37.879)$ & $1.452(27.983)$ & $1.418(25.640)$ \\
& $\mathrm{Ni}$ & $0.462(1.930)$ & $0.268(0.943)$ & $0.505(2.272)$ & $0.756(4.980)$ \\
& $\mathrm{Zn}$ & $1.063(10.65)$ & $1.278(18.53)$ & $1.067(10.92)$ & $1.717(53.55)$ \\
\hline
\end{tabular}

${ }^{1}$ The values in parentheses correspond to the respective raw data means.

The concentrations of the heavy metals depended on the species and the area in which they were collected. There was a statistically significant difference for Pinus brutia trees at mining and control area for the metals $\mathrm{Cd}, \mathrm{Cr}, \mathrm{Cu}, \mathrm{Fe}$ and $\mathrm{Mn}$. Additionally, for Robinia pseudoacacia trees there was a statistically significant difference for the metals $\mathrm{Cd}, \mathrm{Cu}, \mathrm{Fe}, \mathrm{Ni}$ and $\mathrm{Zn}$ between the two studied areas. As well, there was a statistical significantly difference for Cupressus arizona trees at mining and control area for the metals $\mathrm{Cr}, \mathrm{Cu}$ and $\mathrm{Mn}$. Finally, for Populus nigra trees, there was a statistically significant difference for the metals $\mathrm{Co}, \mathrm{Cu}, \mathrm{Fe}$ and Ni between the two studied areas. 
Robinia pseudoacacia and Populus nigra are the only species that showed statistically significant difference for $\mathrm{Zn}$ and Co respectively. Furthermore, copper $(\mathrm{Cu})$ is the only heavy metal that had a statistically significant difference for all the species.

\section{Discussion}

The term heavy metals covers a large group of elements, which are significant both from an industrial and biological point of view, since they have atomic density greater than $6 \mathrm{~g} / \mathrm{cm}^{3}$ [1]. Heavy metals in high concentrations are pollutants and have negative effects on environmental balance and human health $[57,58]$. In the atmosphere mainly, they are found in the form of suspended particles. Thus, the transfer of suspended particles and their deposition on the surface of earth or waters in the form of wet or dry deposition is the first stage of accumulation of atmospheric-origin heavy metals.

In the present research, the average concentration of heavy metals in the leaves of the forest species was $\mathrm{Fe}>\mathrm{Mn}>\mathrm{Zn}>\mathrm{Cu}$, except for the species of black poplar (Populus nigra), where the descending order of metals was $\mathrm{Fe}>\mathrm{Zn}>\mathrm{Mn}>\mathrm{Cu}$. Similar results were obtained also in other studies on trees and other vegetation types (mosses, lichens, sea plants) [10,59-63]. Furthermore, fly ash analysis (for the same area) showed similar concentrations of heavy metals [64]. In particular, for the two conifers (Pinus nigra and Cupressus arizonica) the descending order of metals was $\mathrm{Fe}>\mathrm{Zn}>\mathrm{Mn}>\mathrm{Cu}>\mathrm{Cr}>\mathrm{Ni}>\mathrm{Co}$ for the mining landscapes, for black locust (Robinia pseudoacacia) $\mathrm{Fe}>\mathrm{Mn}>\mathrm{Zn}>\mathrm{Cu}>\mathrm{Ni}>\mathrm{Cr}$ for both sites and for black poplar (Populus nigra) $\mathrm{Fe}>\mathrm{Zn}>\mathrm{Mn}>\mathrm{Cu}>\mathrm{Ni}>\mathrm{Cr}>\mathrm{Co}>\mathrm{Cd}$. A reverse of $\mathrm{Ni}$ and $\mathrm{Cr}$ concentration was observed between coniferous and broad-leaved species and a reverse for $\mathrm{Zn}$ and $\mathrm{Mn}, \mathrm{Cr}$ and $\mathrm{Ni}$ concentrations between the mining landscape and the control area for the conifers. Moreover, only for Populus nigra was cadmium concentration (Cd) possible to measure at both sites, as for other species, the concentration was below ICP detection limits.

Moreover, it was found that among the species which were studied, some show the maximum concentration of a metal and the minimum of another one. So, there was not one sole species with the maximum concentration in all the measured metals. For example, in the region of Ptolemais, the Pinus nigra showed the highest iron concentration and the lowest copper concentration. In addition, for the same region, the Populus nigra had the highest zinc concentration and the lowest iron concentration. Similar conclusions were drawn in research for the same area [62]. Lastly, Populus nigra presented the highest zinc concentration and the lowest iron concentrations. The same correlation was observed in metal concentrations for the same species in the control area as well (K. Grammatiko).

As in most coniferous trees, the needles (scale-like leaves) of both Pinus nigra and Cupressus arizonica remain in the tree for between two and five years. So, they are exposed for a longer period to the polluted air in relation to the leaves of deciduous trees. Pinus nigra's needles are very rough, rigid and jagged on the edges. The scale-like leaves of Cupressus arizonica are very small, plentiful, flake-like, blue-green, with a visible gland on their back, which secretes white resin. The rough surface of the needles and the presence of resin enhance the ability of the Pinus nigra to absorb air pollutants [62]. Beckett et al. [65] stated that coniferous trees have higher air pollutant concentration than broad-leaved trees. From coniferous trees, the pines (Pinus sp.) are those which absorb higher metal amounts and the cypresses (Cupressus sp.), lower. In the present research and for the region of Ptolemais, higher concentrations in $\mathrm{Cr}$, Fe and Ni metals were observed in Pinus nigra, while Cupressus arizonica had higher concentrations in $\mathrm{Co}, \mathrm{Cu}, \mathrm{Mn}$ and $\mathrm{Zn}$ metals.

The Pinus nigra showed statistical differences between the two studied areas for $\mathrm{Cr}, \mathrm{Fe}$ and $\mathrm{Zn}$ metals, which were lower in the control area samples. It should be noted that statistical differences were observed for manganese (Mn) as well, with higher, however, mean concentration in the control area. The same applies for Cupressus arizonica and black poplar species, the average manganese concentration of which was higher in the control area. In black locust, no statistical differences in manganese (Mn) were observed. According to the general caution prevention mechanism [66], the presence of two extreme values for two different metals in the same tree species is due to the different nature of the leaf and the different way that organo-mineral complexes are created in metals. In particular, in Pinus nigra 
(with the highest average Fe concentration and the lowest $\mathrm{Cu}$ concentration), the complexes which are formed with $\mathrm{Fe}$ are more stable than those of $\mathrm{Cu}$. In a similar way, in Populus nigra (with the highest mean $\mathrm{Zn}$ concentration and lowest Fe concentration), the complexes formed with $\mathrm{Zn}$ are more stable than those of Fe. The presence of a metal seems to reduce the absorption or the toxicity of another metal [67], as is confirmed by similar research for the same area [62].

For Cupressus arizonica, statistical differences were observed for three metals ( $\mathrm{Cr}, \mathrm{Fe}$ and $\mathrm{Mn}$ ), between the two research areas. In both coniferous trees, the same descending order in mean metal concentration was observed. Additionally, the same metals showed important differences, apart from $\mathrm{Zn}$, for which, in Cupressus arizonica, no statistical differences were observed between the two areas.

The Robinia pseudoacacia (which was planted mainly for the remediation of the mined areas) has the same descending order as coniferous trees, for four metals, with the highest mean concentration $(\mathrm{Fe}$, $\mathrm{Mn}, \mathrm{Zn}$ and $\mathrm{Cu}$ ), while there was a reversal in the descending order of $\mathrm{Ni}$ and $\mathrm{Cr}$. This reversal in the mean concentrations of the two metals was observed also in Populus nigra. The Populus nigra has dense, felt-like leaves and a network of veins, with one central vein, from which a network of secondary veins starts, traps and retains a great number of particles in an effective way. In Populus nigra, the descending order of the mean concentration of metals is the same as in Robinia pseudoacacia.

All four studied forest species seems to have a significant contribution to the environment, since they retain heavy metals on their leaves. The Pinus nigra retained the highest $\mathrm{Cr}$ and Fe concentrations; Cupressus arizonica $\mathrm{Co}$, Robinia pseudoacacia $\mathrm{Cu}, \mathrm{Mn}$ and $\mathrm{Ni}$ and the Populus nigra $\mathrm{Cd}$ and $\mathrm{Zn}$.

\section{Conclusions}

For the mining area (Ptolemais), the two broad-leaved species, Populus nigra and Robinia pseudoacacia, provided detectable concentrations for $\mathrm{Cd}$. For this reason, they should be considered as appropriate species for bioindicators of this particular metal in impacted locations.

Robinia pseudoacacia should be avoided in Co pollution studies, since it is the only species which did not provide detectible concentrations.

$\mathrm{Ni}$ and $\mathrm{Mn}$ showed similar concentrations among the species, which means that the research for the former leads to safe conclusions also for the latter.

Generally, we conclude that plantation and selection of proper forest species (coniferous and broad-leaved) contribute to enhancement of the environment and the remediation of the mined areas of PPC-Ptolemais, since tree leaves are the main absorbers of heavy metals and air pollutants in general.

Author Contributions: "Heavy metal retention by different forest species used for restoration of post-mining landscapes, N. Greece" conception and experiment design: T.S., I.S., P.P. and T.G.P. Laboratory chemical analyses and analysis and interpretation of the data: T.S. Critical revision of the article: I.S., P.P. and T.G.P. T.S. takes responsibility for the integrity of the work as a whole from the inception to the finished article. All authors have read and agreed to the published version of the manuscript.

Funding: This research received funding from Public Power Company (PPC) of Greece, within the research program 'Woody species selection for environmental restoration at Ptolemais area mines of "PPC" and Forest Research Institute of Thessaloniki (TGP was the scientific coordinator).

Acknowledgments: The authors wish to thank E. Havales for his help with field data. The authors are grateful to Psoma Polyxeni and Mpountla Areti of chemical analysis in the laboratory of the Soil Science Institute of Thessaloniki, ELGO-DEMETER and Menexes Georgios for his advices on the statistical analyses of data.

Conflicts of Interest: The authors declare no conflict of interest.

\section{References}

1. Alloway, B.J. Heavy Metals in Soils; Blackie Academic and Professional: London, UK, 1995.

2. Papadopoulos, A.; Prochaska, C.; Papadopoulos, F.; Gantidis, N.; Metaxa, E. Levels of heavy metals in topsoils of Servia municipality, western Macedonia, Greece. In Proceedings of the 10th International Conference on Environmental Science and Technology, Kos island, Greece, 5-7 September 2007; pp. 1103-1108.

3. Alfani, A.; Batrol, G.; Rutigliano, F.A.; Maisto, G.; Virzo De Santo, A. Trace metal biomonitoring in the soil and the leaves of Quercus Ilex in the urban area of Naples. Biol. Trace Elem. Res. 1996, 51, 117-131. [CrossRef] 
4. Pyatt, F.B. Copper and lead bioaccumulation by Acacia retinoides and Eucalyptus torquatain sites contaminated as a consequence of extensive ancient mining activities in Cyprus. Ecotoxicol. Environ. Saf. 2001, 50, 60-64. [CrossRef] [PubMed]

5. Avila, A.; Alarcon, M.; Rodrigo, A. Heavy metal deposition and cycling at two Mediterranean holm oak (Quercus ilex L.) forests in northeastern Spain. J. Phys. IV 2003, 107, 75-78.

6. Urbat, M.; Lehndorff, E.; Schwark, L. Biomonitoring of air quality in the Cologne Conurbation using pine needle as a passive sampler-Part I: Magmetic properties. Atmos. Environ. 2004, 38, 3781-3792. [CrossRef]

7. Maisto, G.; Alfani, A.; Baldantoni, D.; De Marco, A.; Virzo De Santo, A. Trace metals in the soil and in Quercus ilex L. leaves at anthropic and remote sites of the Campania Region of Italy. Geoderma 2004, 122, 269-279. [CrossRef]

8. Sardans, J.; Penuelas, J. Trace element accumulation in the moss Hypnum cupressiforme Hedw. and trees Quercuc ilex L. and Pinus halepensis Mill. in Catalonia. Chemosphere. 2005, 60, 1293-1307. [CrossRef]

9. Platis, P.; Papachristou, T.; Spanos, I.; Meliadis, I.; Kazantzidis, S.; Halivopoulou, C.; Giakzidis, C.; Mantzanas, K. Special Landscaping Design for Rehabilitation of Mining Area Vegetation Ptolemais Regional Unity Kozani under ICM PPC; National Agricultural Research Foundation, Forest Research Institute: Thessaloniki, Greece, 2011; p. 186. (In Greek)

10. Sawidis, T.; Metentzoglou, E.; Mitrakas, M. A study of chromium, cooper and lead distribution from lignite fuels using cultivated and non-cultivated plants as biological monitors. Water Air Soil Pollut. 2011, 220, 339-352. [CrossRef]

11. Moreno, E.; Sagnotti, L.; Dinares-Turell, J.; Winkler, A.; Cascella, A. Biomonitoring of traffic air pollution in Rome using magnetic properties of tree leaves. Atmos. Environ. 2003, 37, 2967-2977. [CrossRef]

12. Gratani, L.; Crescente, M.F.; Varone, L. Long-term monitoring of metal pollution by urban trees. Atmos. Environ. 2008, 42, 8273-8277. [CrossRef]

13. Beckett, K.P.; Free-Smith, P.; Taylor, G. Urban Woodlands: Their role in reducing the effect of particulate pollution. Environ. Pollut. 1998, 99, 347-360. [CrossRef]

14. Nowak, D.J. Air pollution removal by Chicago's urban forest. In Chicago's Urban Forest Ecosystem: Results of the Chicago's Urban Forest Climate Project, General Technical Report NE-186; McPherson, E.G., Nowak, D.J., Rowntree, R.A., Eds.; U.S. Department of Agriculture: Radnor, PA, USA, 1994; pp. 63-84.

15. Taha, H. Modeling impacts of in the South Coast Air Basin. Atmos. Environ. 1996, 30, 3423-3430. [CrossRef]

16. Nowak, D.J.; Dwyer, J.F. Understanding the benefits and costs of urban forest ecosystems. In Handbook of Urban and Community Forestry in the Northeast; Kuser, J.E., Ed.; Kluwer Academic/Plenum Publishers: New York, NY, USA, 2000; pp. 11-22.

17. Iordanidis, A.; Georgakopoulos, A. Pliocene lignites from Apofysis mine, Amynteo basin, Northwestern Greece: Petrographical characteristics and depositional environment. Int. J. Coal Geol. 2003, 54, 57-68. [CrossRef]

18. Papamichos, N. T Forest Soil; Publications Service of AUTH: Thessaloniki, Greece, 1996. (In Greek)

19. Triantafyllou, G.A. $\mathrm{PM}_{10}$ pollution episodes as a function of synoptic climatology in a mountainous industrial area. Environ. Pollut. 2001, 112, 491-500. [CrossRef]

20. Georgakopoulos, A.; Filippidis, A.; Kassoli-Fournaraki, A.; Iordanidis, A.; Fernandez-Turiel, J.L.; Liorens, J.F.; Gimeno, D. Environmentally important elements in fly ashes and their leachates of the power stations of Greece. Energy Sources 2002, 24, 83-91. [CrossRef]

21. Triantafyllou, G.A. Levels and trends of suspended particles around large lignite power stations. Environ. Monit. Assess. 2003, 89, 15-34. [CrossRef]

22. Petaloti, C.; Triantafyllou, A.; Kouimtzis, T.; Samara, C. Trace elements in atmospheric particulate matter over a coal burning power production area of western Macedonia, Greece. Chemosphere 2006, 65, 2233-2243. [CrossRef] [PubMed]

23. Cicek, A.; Koparal, A.S. Accumulation of sulfur and heavy metals in soil and tree sampled from the surroundings of Tuncbilek Thermal Power Plant. Chemosphere 2004, 57, 1031-1036. [CrossRef] [PubMed]

24. Smith, W.H.; Staskawawicz, B.J. Removal of atmospheric particles by leaves and twings of urban trees: Some preliminary observations and assessment of research needs. Environ. Manag. 1977, 1, 317-330. [CrossRef]

25. Martin, M.H.; Coughtrey, P.J. Biological Monitoring of Heavy Metal Pollution. Land and Air; Applied Science Publishers: London, UK, 1982; p. 475. 
26. Dickinson, N.M.; Turner, A.P.; Lepp, N.W. Survival of trees in a metal-contaminated environment, Part III. Water Air Soil Pollut. 1991, 57-58, 627-633. [CrossRef]

27. Sawidis, T.; Marnasidis, A.; Zachariadis, G.; Stratis, J. A study of air-pollution with heavy-metals in Thessaloniki City (Greece) using trees as biological indicators. Arch. Environ. Contam. Toxicol. 1995, 28, 118-124. [CrossRef]

28. Beckett, K.P.; Free-Smith, P.; Taylor, G. The capture of particulate pollution by trees at five contrasting urban sites. Arboric. J. 2000, 24, 209-230. [CrossRef]

29. Pal, A.; Kulshreshtha, K.; Ahmad, K.J.; Behl, H.M. Do leaf surface characters play a role in plant resistance to auto-exhaust pollution? Flora 2002, 197, 47-55. [CrossRef]

30. Pourkhabbaz, A.; Rastin, N.; Olbrich, A.; Langenfeld-Heyser, R.; Polle, A. Influence of environmental pollution on leaf properties of urban plane trees, Platanus orientalis L. Bull. Environ. Contam. Toxicol. 2010, 85, 251-255. [CrossRef] [PubMed]

31. Taylor, H.J.; Ashmore, M.R.; Bell, J.N.B. Air Pollution Injury to Vegetation; IEHO: London, UK, 1990.

32. Al-Shayed, S.M.; Al-Rajhi, M.A.; Seaward, M.R.D. The date palm (Phoenix dactylifera L.) as a biomonitor of lead and other elements in arid environments. Sci. Total Environ. 1995, 168, 1-10. [CrossRef]

33. Al-alawi, M.; Mandiwana, K. The use of Alepo pine as a bio-monitor of heavy metals in atmosphere. J. Hazard. Mater. 2007, 148, 43-46. [CrossRef]

34. Kovács, M. Trees as biological indicators. In Biological Indicators in Environmental Protection; Kovács, M., Ed.; Ellis Horwood: New York, NY, USA, 1992.

35. Kovács, M. Biological Indicators in Environmental Protection; Ellis Horwood: New York, NY, USA, 1992.

36. Rasmussen, P.E.; Mierle, G.; Nriagu, J.O. The analysis of vegetation for total mercury. Water Air Soil Pollut. 1991, 56, 379-388. [CrossRef]

37. Ceburnis, D.; Steinnes, E. Conifer needles as bio-monitors of atmospheric heavy metal deposition: Comparison with mosses and precipitation, role of the canopy. Atmos. Environ. 2000, 34, 4265-4271. [CrossRef]

38. Holoubek, I.; Korinek, P.; Seda, Z.; Schneiderova, E.; Holoubkova, I.; Pacl, A.; Triska, J.; Cudlin, P.; Caslavsky, J. The use of mosses and pine needles to detect persistent organic pollutants at local and regional scales. Environ. Pollut. 2000, 109, 283-292. [CrossRef]

39. Migaszewski, Z.M.; Galuszka, A.; Paslawski, P. Polynuclear aromatic hydrocarbons; phenols and trace metals in selected soil profiles and plant bio-indicators in the Holy Cross Mountains, South-Central Polant. Environ. Int. 2002, 28, 303-313. [CrossRef]

40. Chapman, H.D.; Pratt, P.F. Methods of Analysis for Soils; Plants and Waters; University of California Berkeley, Division of Agriculture Sciences: Berkeley, CA, USA, 1961.

41. Baker, D.; Gorsline, G.W.; Smith, C.G.; Thomas, W.I.; Grube, W.E.; Ragland, J.L. Techniques for rapid analysis of corn leaves for eleven elements. Agron. J. 1964, 56, 133-136. [CrossRef]

42. Wear, J.I.; Boron, P. Methods of Soil Analysis, Part 2; Agron. Monpgr. 9; Black, C.A., Ed.; ASA: Madison, WI, USA, 1965; pp. 1059-1063.

43. Issac, R.A.; Jones, J.B. Jr. Effects of various dry ashing temperatures on the determination of 13 elements in five plant tissues. Commun. Soil Sci. Plant Anal. 1972, 3, 261-269. [CrossRef]

44. Gaines, T.P.; Mitchell, G.A. Boron determination in plant tissues by the azomethine H method. Commun. Soil Sci. Plant Anal. 1979, 10, 1099-1108. [CrossRef]

45. Loshe, G. Microanalytical azomethine-H method for boron determination in plant tissue. Commun. Soil Sci. Plant Anal. 1982, 13, 127-134.

46. Munter, R.C.; Halverson, T.L.; Anderson, R.D. Quality assurance of plant tissue analysis by ICP-AES. Commun. Soil Sci. Plant Anal. 1984, 15, 1285-1322. [CrossRef]

47. Soltanpour, P.N.; Johnson, S.M.; Workman, S.M.; Jones, J.B.; Miller, R.O. Inductively coupled plasma emission spectrometry. In Methods of Soil Analysis: Part 3 Chemical Methods 3rd; Book Series No., 5, Bartels, I.M., Eds.; ASA and SSSA: Madison, WI, USA, 1996; pp. 91-139.

48. Gavlak, R.; Horneck, D.; Miller, R. Soil; Plant and Water Reference Methods for the Western Region, 3rd ed.; WREP 125: Fairbanks, AK, USA, 2005.

49. Zar, J. Biostatistical Analysis; Prentice-Hall International, Inc.: Upper Saddle River, NJ, USA, 1996.

50. Rencher, A. Linear Models in Statistics; John Willey \& Sons, Inc.: New York, NY, USA, 2000.

51. Toothaker, L. Multiple Comparison Procedures; Sage Publications, Inc.: Thousand Oaks, CA, USA, 1993. 
52. Hodgson, D.R.; Townsend, W.N. The amelioration and revegetation of pulverized fuel ash. In Ecology and Reclamation of Devastated Land; Huntnik, R.J., Davis, G., Eds.; Gordon and Breach: London, UK, 1973; Volume 2, pp. 247-270.

53. Andriano, D.C.; Page, A.L.; Elseewi, A.A.; Chang, A.C.; Straughan, I. Utilization and disposal of fly ash and other coal residues in terrestrial ecosystems: A review. J. Environ. Qual. 1980, 9, 333-344. [CrossRef]

54. El-Mogazi, D.D.; Lisk, D.J.; Weinstein, L.H. A review of physical, chemical and biological properties of fly ash and effects on agricultural ecosystems. Sci. Total Environ. 1988, 74, 1-37. [CrossRef]

55. Carlson, C.L.; Andriano, D.C. Environmental impacts of coal combustion residues. J. Environ. Qual. 1993, 22, 227-247. [CrossRef]

56. Pavlovic, P.; Mitrovic, M.; Djurdjevic, L. An ecophysiological study of plants growing on the fly ash deposits from the "Nicola Tesla-A" thermal power station in Serbia. Environ. Manag. 2004, 33, 654-663. [CrossRef]

57. Leyval, C.; Turnau, K.; Haselwandter, K. Effect of heavy metal pollution on mycorrhizal colonization and function: Physiological, ecological and applied aspects. Mycorrhiza 1997, 7, 139-153. [CrossRef]

58. Kabata-Pedias, A. Trace Elements in Soils and Plants; CRC: Boca Raton, FL, USA, 2001.

59. Sawidis, T.; Zachariadis, G.; Stratis, J.; Ladukakis, E. Mosses as biological indicators for monitoring of heavy-metal pollution. Fresenius Environ. Bull. 1993, 2, 193-199.

60. Sawidis, T.; Chettri, A.; Zachariadis, G.; Stratis, J. Heavy metals in aquatic plants and sediments from water system in Macedonia, Greece. Exotoxicol. Environ. Saf. 1995, 32, 73-80. [CrossRef] [PubMed]

61. Sawidis, T.; Chettri, A.; Zachariadis, G.; Stratis, J.; Seaward, M.R.D. Heavy metal bioaccumulation in lichens from Macedonia in northern Greece. Toxicol. Environ. Chem. 1995, 50, 157-166. [CrossRef]

62. Sawidis, T.; Chettri, A.; Papaioannou, A.; Zachariadis, G.; Stratis, J. A study of metal distribution from lignite fuels using trees as biological indicators. Ecotoxicol. Environ. Stud. 2001, 48, 27-35. [CrossRef]

63. Samara, T.; Tsitsoni, T. Selection of forest species for use in urban environment in relation to their potential capture to heavy metals. Glob. Nest J. 2014, 16, 966-974.

64. Stratis, J.A.; Tsitouridou, R.D.; Simeonov, D.V. Chemometrical data treatment to study the environmental pollution around lignite power plants. Toxicol. Environ. Chem. 1993, 47, 71-76. [CrossRef]

65. Beckett, K.P.; Free-Smith, P.; Taylor, G. Effective tree species for local air-quality management. J. Arboric. 2000, $26,12-19$.

66. Wehrli, B.; Stumm, W. Vanadyl in natural waters: Absorption and hydrolysis promote oxygenation. Geochim. Cosmochim. Acta 1989, 53, 69-77. [CrossRef]

67. Streit, B.; Stumm, W. Chemical properties of metals and process of bioaccumulation in terrestrial plants. In Plants as Biomonitors; Market, B., Ed.; VCH Publishers: Weinheim, Germany, 1993; pp. 31-36. 